\title{
Microwave-assisted Preparation of Cross-linked Gelatin-Paracetamol Matrices: Optimization Using the D-optimal Design
}

\author{
Çapraz Bağlı Parasetamol Matrikslerinin Mikrodalga Yardımıyla \\ Hazırlanması: D-optimal Tasarımı Kullanılarak Optimizasyon
}

\author{
(D) Tan Kian KUANG1, (D) Yew-Beng KANG22, (D) Ignacio SEGARRA 1,3 , (D) Ummarah KANWAL4 , (D) Muhammad AHSAN4 , (D) Nadeem Irfan BUKHARI1,4* \\ 1 International Medical University School of Pharmacy, Department of Pharmaceutical Technology, Kuala Lumpur, Malaysia \\ 2International Medical University School of Pharmacy, Department of Pharmaceutical Chemistry, Kuala Lumpur, Malaysia \\ 3Department of Pharmacy, School of Health Sciences and Pharmacy, Catholic University of Murcia, Murcia, Spain \\ 4Punjab University College of Pharmacy, University of the Punjab, Lahore, Pakistan
}

\begin{abstract}
Objectives: This study was conducted to assess the effect of microwave heating on the preparation of paracetamol cross-linked gelatin matrices by using the design of experiment (DoE) approach and explore the influence of the duration of microwave irradiation, the concentrations of crosslinker, and the amount of sodium bicarbonate (salt) on paracetamol release. These parameters were also compared with those of the matrices prepared via conventional heating.

Materials and Methods: Twenty gel matrices were prepared with different durations of microwave irradiation, amounts of maize, and concentrations of sodium bicarbonate as suggested by Design Expert (DX $\left.{ }^{\circledR}\right)$. The percentage drug release, the coefficient of variance (CV) in release, and the mean dissolution time (MDT) were the properties explored in the designed experimentation.

Results: Target responses were dependent on microwave irradiation time, cross-linker amount, and salt concentration. Classical and microwave heating did not demonstrate statistically significant difference in modifying the percentage of drug released from the matrices. However, the CVs of microwave-assisted formulations were lower than those of the gel matrices prepared via classical heating. Thus, microwave heating produced lesser variations in drug release. The optimized gel matrices demonstrated that the observed percentage of drug release, CV, and MDT were within the prediction interval generated by $D X^{\circledR}$. The release mechanism of the matrix formulations followed the Peppas-Korsmeyer anomalous transport model.
\end{abstract}

Conclusion: The DoE-supported microwave-assisted approach could be applied to optimize the critical factors of drug release with less variation. Key words: Controlled release gel matrices, paracetamol, microwave heating, classical heating, experiment design

öz

Amaç: Bu çalışma mikrodalga ısıtmasının parasetamol çapraz bağlı jelatin matriksleri üzerine etkisini değerlendirmek ve mikrodalga ışıma süresinin etkisini, çapraz bağlayıcıların konsantrasyonlarını ve parasetamol salımı üzerinde sodyum bikarbonat tuzunun miktarını bulmak üzere gerçekleştirilmiştir. Bu parametreler konvansiyonel ısıtma yöntemleriyle hazırlanan matrikslerle de karşılaştırılmıştır.

Gereç ve Yöntemler: Yirmi jel matriks Design Expert (DX $\left.{ }^{\circledR}\right)$ tarafından önerilen farklı mikrodalga ışıma süresi, farklı miktarda mısır ve farklı konsantrasyonlarda sodyum bikarbonat kullanılarak hazırlanmıştır. İlaç salımının yüzdesi salımdaki varyans katsayısı (CV) ve ortalama dissolüsyon zamanı (MDT) tasarımlandırılmış deneylerle araștırılmıștır.

Bulgular: Hedef yanıtlar mikrodalga ışıma süresi, çapraz bağlayıcı miktarı ve tuz konsantrasyonuna bağlı bulunmuştur. Klasik ve mikrodalga ısıtma matrikslerden ilacın salım yüzdesi üzerine istatistiksel olarak anlamlı bir fark oluşturmamıștır. Ancak, mikrodalga ile olușturulan formülasyonların CV'leri klasik ısıtma ile oluşturulan jel matrikslerden düşük bulunmuştur. Ayrıca, mikrodalga ısıtma ilaç salımında daha az varyasyon oluşturmuştur. Optimize jel matriksler gözlenen ilaç salımının yüzdesi, CV ve MDT DX ${ }^{\circledR}$ tarafından olușturulan tahmini interval içinde bulunmuștur. Matriks formülasyonların salınım mekanizması Peppas-Korsmeyer kuraldışı taşınım modeline uymuştur.

*Correspondence: nadeem_irfanQhotmail.com, Phone: +92 42 99211616, ORCID-ID: orcid.org/0000-0001-5710-9574

Received: 25.10.2019, Accepted: 01.04.2020

@T Turk J Pharm Sci, Published by Galenos Publishing House. 
Sonuç: DoE ile desteklenen mikrodalga ile gerçekleştirilen yaklaşım ilaç salnımının kritik faktörlerini optimize etmekte daha düşük varyasyonu sağlamak için uygulanabilir.

Anahtar kelimeler: Kontrollü salımlı jel matriksler, parasetamol, mikrodalga ısıtma, klasik ısıtma, deney tasarımı

\section{INTRODUCTION}

Controlling the release of drugs from a polymeric matrix is challenging in the development of controlled release dosage forms because of the different release patterns and physicochemical properties of drugs.,2 Drug release can be delayed by cross-linking a drug with polymeric matrices. ${ }^{3}$ Chemical cross-linking is associated with the production of chemical cross-linker residuals; nevertheless, this problem can be overcome by using biopolymers that can be cross-linked with natural and non-toxic cross-linkers, such as maize, because of their safety, biodegradability, and biocompatibility. Microwaveassisted methods can also be used for cross-linking and developing dosage forms. . $^{4-6}$ Microwave emits electromagnetic radiations with a frequency of $300 \mathrm{GHz}$ to $300 \mathrm{MHz}$. Most commercial microwave ovens produce a microwave wavelength of $12.25 \mathrm{~cm}$, which is equivalent to $2.45 \mathrm{GHz}^{6}$. Microwave heating can modify the state of molecular interactions between polymer chains to control physicochemical properties and drug release. Microwave energy is absorbed by materials, converted into molecular kinetic energy, and dissipated by molecules because of the inertial, elastic, and frictional forces of the surroundings. Its specific heating causes dipolar polarization and promotes cross-linking without using harsh solvents., ${ }^{7,8}$ Carbohydrate polymers, such as alginate, gelatin, and cellulose, have been incorporated in controlled release drug delivery systems., Sodium alginate is a water-soluble biopolymer, which is cross-linked in the presence of multivalent cations in aqueous media. It may form a hydrogel upon cross-linking. ${ }^{3}$ Calcium alginate-coated matrices significantly reduce the percentage of drugs released by the main matrix structure.' Gelatin is a natural polymer rarely used alone, because of its low intensity and high brittleness unless it is modified by several methods, such as cross-linking, grafting, and blending. Traditional experimentation for optimizing multiple factors of formulations is time consuming and does not reveal factor interactions, which may be synergistic or antagonistic. Conversely, the design of experiment (DoE) determines the relationship between factors and responses, reveals factor interactions, and facilitates the development of optimized formulations with lesser time, cost, and material consumption. 2,9 The factors that may affect microwave-assisted cross-linking include microwave power, microwave exposure time, and temperature. The concentrations of macromolecules, cross-linkers, and salts and the nature of drugs may be the other factors that should be considered in designing a gel formulation.

This study was performed to assess the effect of microwave heating in the presence of a cross-linker and salt on crosslinking and drug release characteristics of gelatin matrices. This study was also conducted to optimize the above conditions for the release of a drug via the DoE approach. The model drug used in this study was paracetamol, a water-soluble drug, because of its availability and lack of risks in handling by being an over-the-counter drug, which can be rigorously tested in a study. ${ }^{10}$

\section{MATERIALS AND METHODS}

\section{Chemicals and reagents}

Paracetamol BP (Zulat Pharmacy, China), gelatin (R\&M Chemicals), maize (National Starch \& Chemical), potassium dihydrogen orthophosphate $\left(\mathrm{KH}_{2} \mathrm{PO}_{4}\right.$; Fisher Scientific, UK), and disodium hydrogen phosphate dihydrate $\left(\mathrm{Na}_{2} \mathrm{HPO}_{4} \cdot 2 \mathrm{H}_{2} \mathrm{O}\right.$; Merck, Germany) were used. Sodium hydroxide ( $\mathrm{NaOH}, \mathrm{A}$. R. grade, purity 99\%, MW 40; Batch no. 020606; JRL, System ${ }^{\circledR}$ ) was utilized to prepare $0.1 \mathrm{M} \mathrm{NaOH}$ solution. All the other materials and reagents were of analytical grade.

\section{Preparation of gelatin-paracetamol matrices}

Microwave power from $10 \%$ to $100 \%$ and irradiation time from $10 \mathrm{~s}$ to $60 \mathrm{~s}$ were varied to generate a temperature of $60^{\circ} \mathrm{C}$. $^{11}$ The maximum amount of paracetamol to be added was determined on the basis of its weight (grams) dissolved in a predefined volume of water with or without using a sonicator. The time of drug dissolution was also noted.

The amount of maize (as fructose) was changed within 0.5-2.5 $\mathrm{g}$, sodium bicarbonate within 2-4 g, and duration of irradiation from $20 \mathrm{~s}$ to $50 \mathrm{~s}$ by using the D-optimal design implanted in Design Expert $\left(D X^{\circledR}\right)$ version 12 to generate an experimental matrix (Table 1).12 The amounts of paracetamol $(0.4 \mathrm{~g})$ and gelatin (9.3 g), microwave irradiation power (30\%), and stirring time (30 s) were fixed. All the above ingredients were dissolved with stirring for $30 \mathrm{~s}$ in 22.2-26.2 $\mathrm{mL}$ of water to keep the total number of parts at 38.4 . The resultant mass was exposed to $30 \%$ microwave power (input: $1.60 \mathrm{~kW}$, output: $1100 \mathrm{~W}$, and frequency: $2450 \mathrm{MHz}$; Sharp equipped with a magnetron emitter) for $50 \mathrm{~s}$ to achieve $60^{\circ} \mathrm{C}$ and maintain drug stability. Twenty matrices were prepared and incubated (230 V, $3.9 \mathrm{~A}$, $50 / 60 \mathrm{~Hz}$, and $900 \mathrm{~W}$; Memmert type BE 500, Germany) at $37^{\circ} \mathrm{C}$ for $17 \mathrm{~h}$.

\section{In vitro drug release study}

Paracetamol-gelatin matrices were subjected to an in vitro drug release study with Franz diffusion cells (PermeGear, Inc., USA; Figure 1a) fitted with a thermostat (CC1, Huber, D77656, Figure 1a) in phosphate buffer $(\mathrm{pH}=5.8)$ set at $37^{\circ} \mathrm{C} \pm 2^{\circ} \mathrm{C}$ by utilizing a Visking membrane (VM) with a thickness of $0.0145 \mathrm{~cm}$ and a pore size of $0.45 \mu \mathrm{m}$ (Whatman ${ }^{\circledR}$ International Ltd., Maidstone, England). Before the experimentation, the $\mathrm{VM}$ was heated in $2 \%$ sodium bicarbonate and $1 \mathrm{mM}$ EDTA at $80^{\circ} \mathrm{C}$ for $30 \mathrm{~min}$ and rinsed with dissolution media.13,14 The receiver compartment was loaded with a dissolution medium and a magnetic stirrer. The membrane was mounted between the donor and receptor 
compartments and clamped (Figure 1b). The conditions for the release study $(\mathrm{pH}$, membrane type, membrane treatment, and rpm of magnetic stirrer) were set for the maximum release after screening experimentations.

The donor compartment was filled with a test sample and covered with parafilm to prevent sample leakage. The magnetic stirrer was rotated at $300 \mathrm{rpm}$. The sample $(1 \mathrm{~mL})$ was withdrawn initially at 5, 15, 30, and 45 min and subsequently at 1, 2, 3, 5, and $8 \mathrm{~h}$ from the receiver compartment and replenished with fresh dissolution media. ${ }^{15}$ The paracetamol concentration was

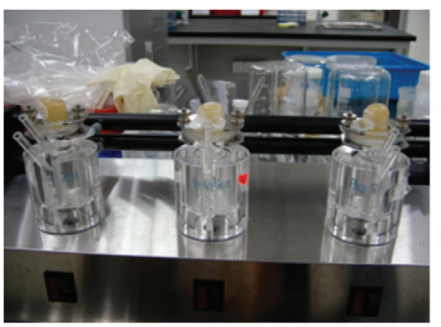

a b

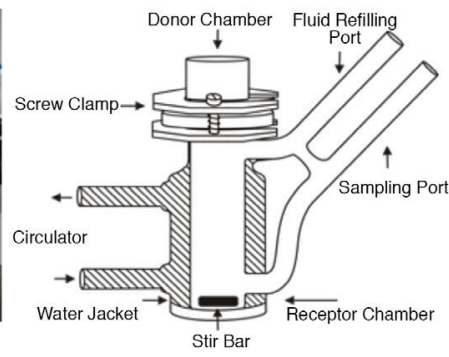

Figure 1. (a, b) Franz diffusion cells

Table 1. Experimental layout of the production of the optimized paracetamol matrices

\begin{tabular}{|c|c|c|c|c|}
\hline Matrix & $\begin{array}{l}\text { Time of } \\
\text { irradiation (s) }\end{array}$ & $\begin{array}{l}\text { Maize } \\
\text { (g) }\end{array}$ & $\begin{array}{l}\text { Na bicarbonate } \\
\text { (g) }\end{array}$ & $\begin{array}{l}\text { Water } \\
(\mathrm{mL})\end{array}$ \\
\hline 1 & 20 & 1.5 & 4.0 & 23.2 \\
\hline 2 & 20 & 0.5 & 2.0 & 26.2 \\
\hline 3 & 35 & 0.5 & 3.0 & 25.2 \\
\hline 4 & 50 & 0.5 & 4.0 & 24.2 \\
\hline 5 & 20 & 0.5 & 4.0 & 24.2 \\
\hline 6 & 50 & 2.5 & 4.0 & 22.2 \\
\hline 7 & 50 & 1.5 & 3.0 & 24.2 \\
\hline 8 & 50 & 0.5 & 4.0 & 24.2 \\
\hline 9 & 50 & 0.5 & 2.0 & 26.2 \\
\hline 10 & 50 & 2.5 & 2.0 & 24.2 \\
\hline 11 & 35 & 2.0 & 3.5 & 23.2 \\
\hline 12 & 50 & 0.5 & 2.0 & 26.2 \\
\hline 13 & 20 & 0.5 & 2.0 & 26.2 \\
\hline 14 & 20 & 2.5 & 2.0 & 24.2 \\
\hline 15 & 20 & 2.5 & 3.0 & 23.2 \\
\hline 16 & 35 & 1.5 & 2.0 & 25.2 \\
\hline 17 & 50 & 2.5 & 2.0 & 24.2 \\
\hline 18 & 35 & 0.5 & 2.0 & 26.2 \\
\hline 19 & 50 & 2.5 & 4.0 & 22.2 \\
\hline 20 & 20 & 2.5 & 4.0 & 22.2 \\
\hline
\end{tabular}

determined with a ultraviolet spectrophotometer (Shimadzu, model 1240, Japan) at $244 \mathrm{~nm}$ by using calibration curves in the media. ${ }^{10}$

\section{Preparation of optimized and control gelatin-paracetamol matrices}

The percentage of drug release, coefficient of variance (CV), and mean dissolution time (MDT) were calculated, and the release mechanism was noted with PCP Disso v3. All the outputs were entered in the generated template and analyzed using $D X^{\circledR}$. The best mathematical model for each response was selected on the basis of the statistical parameters. The optimized formulation based on the best levels of the factors given by DoE was prepared and labeled as the validation formulation, and drug release was studied. ${ }^{16}$ Control gelatin matrices were prepared with the optimized factor levels but were exposed to classical heat with a hot plate equipped with a digital magnetic stirrer (MSH-20D, Daihan Labtech Co. Ltd., WiseStir $\left.{ }^{\circledR}\right)$ instead of microwave heating. The target temperature was $60^{\circ} \mathrm{C} .{ }^{10}$

\section{Thermal analysis of the control and optimized matrices}

Differential scanning calorimetry [(DSC), Mettle Toledo, Switzerland] was performed to thermally analyze the control and optimized matrices. The samples of weight of $5-10 \mathrm{mg}$ were crimpled in a standard aluminum pan by using a crucible sealing press. Hermetically sealed aluminum pans were heated from $20^{\circ} \mathrm{C}$ to $200^{\circ} \mathrm{C}$ at a rate of $10^{\circ} \mathrm{C} / \mathrm{min}$ under constant nitrogen flow at $20 \mathrm{~mL} / \mathrm{min}$ to record DSC thermograms.

\section{Statistical analysis}

The release data after classical heating (control) and microwave heating were compared via Mann-Whitney $U$ test statistics in SPSS at a significance level of $p<0.05$.

\section{RESULTS}

In this study, a smooth and swellable paracetamol gel matrix was obtained from $0.4 \mathrm{~g}$ of paracetamol dissolved in $24 \mathrm{~mL}$ of water in a bath sonicator for 45 min under varying cross-linker concentrations, microwave power, and radiation exposure (Figure 2a). A minimum of $30 \%$ microwave power upon exposure to microwave energy for $50 \mathrm{~s}$ helped achieve $60^{\circ} \mathrm{C}$.

Figure $2 \mathrm{~b}$ shows that the pure paracetamol solution achieved $68.35 \%$ drug release (permeation) until the last time point ( 8 h). This value was higher than that from all the cross-linked matrices (8.82\%-35.51\%). The drug release of cross-linked matrices 8 and 9 was higher after $6 \mathrm{~h}$ as compared to the rest of the matrices. The CV of the drug release for the majority of matrices at $0.083 \mathrm{~h}$ was comparatively higher than that at the other time points. However, the value of this parameter was lesser at the later time intervals. MDT was increased from $0.04 \mathrm{~h}$ at $1 \mathrm{~h}$ to $5.05 \mathrm{~h}$ after $8 \mathrm{~h}$. The maximum coefficient of relationship indicated that paracetamol released from microwave-treated cross-linked matrices followed the Peppas model except matrix 18 , which was fitted to the first-order kinetics. The percentage of drug release at $1 \mathrm{~h}$ slightly decreased when the irradiation time was extended from $20 \mathrm{~s}$ to $35 \mathrm{~s}$ at low cross-linker concentrations (Figure 3a-e). MDT at 1, 3, and 8 h (Figure 4a-d) 


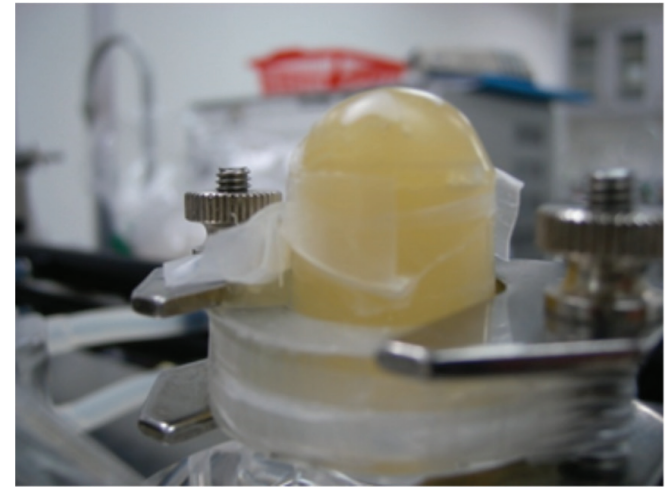

a

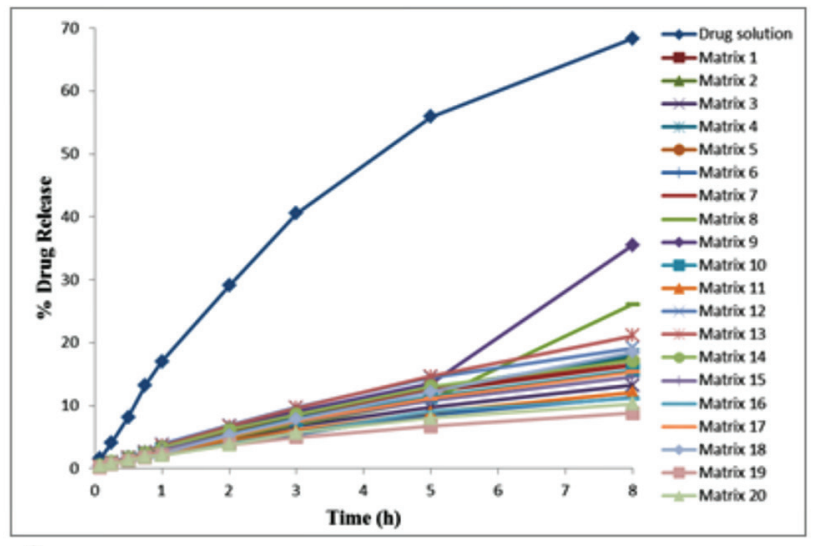

b

Figure 2. (a) Paracetamol swellable gel matrices. (b) Drug release (\%) of paracetamol solution and cross-linked matrices 1-20 designed by $D X^{\circledR}$ for $8 \mathrm{~h}$

$\mathrm{DX}^{\oplus}$ : Design Expert were lower in matrices that had high concentrations of salt and cross-linker and were exposed to microwave energy for $50 \mathrm{~s}$ as compared to the matrices having lower amounts of salt and cross-linker. The response plot showed a saddle-shaped surface for MDT at 1 and $5 \mathrm{~h}$. The same decreasing trend was observed in MDT until $8 \mathrm{~h}$. The CV was increased from 3.51 to 14.83 as the duration of microwave exposure increased from $20 \mathrm{~s}$ to $50 \mathrm{~s}$ at $3 \mathrm{~h}$ (Figure $5 \mathrm{a}-\mathrm{d}$ ). It was also increased in the presence of moderately high levels of sodium bicarbonate and prolonged microwave exposure. Conversely, it was not affected by the increased maize levels.

The DoE-predicted combinations of maize, sodium bicarbonate, and radiation exposure time for the desired properties of outputs, namely, lower release, least $\mathrm{CV}$, and lower variations in drug release, were $2.50 \mathrm{~g}, 2 \mathrm{~g}$, and $45 \mathrm{~s}$, respectively. The amount of gelatin, drug, and water were fixed at $9.30 \mathrm{~g}, 0.40$ $\mathrm{g}$, and $24.2 \mathrm{~mL}$, respectively. Based on the composition of matrices and conditions of their preparation, the optimized and control matrices showed responses, such as percent release, CV of release and MDT as given in Table 2 .

Three control matrices were prepared using the same optimized factor levels via classical heating at $60^{\circ} \mathrm{C}$ instead of microwave heat exposure. The percentages of drug release from the optimized and control formulations were almost similar and best described with the Peppas model (Figure 6a). For the majority of the release time points, the Mann-Whitney $U$ test revealed no difference between classical heating (control) and microwave heating ( $p>0.05$ ). Only the percentage of drug release at 5 h, CV at 5 and $8 \mathrm{~h}$, and MDT at $0.75 \mathrm{~h}$ significantly differed between the optimized and control formulations ( $p<0.05$ ). However, the standard deviation of the matrices exposed to classical heat
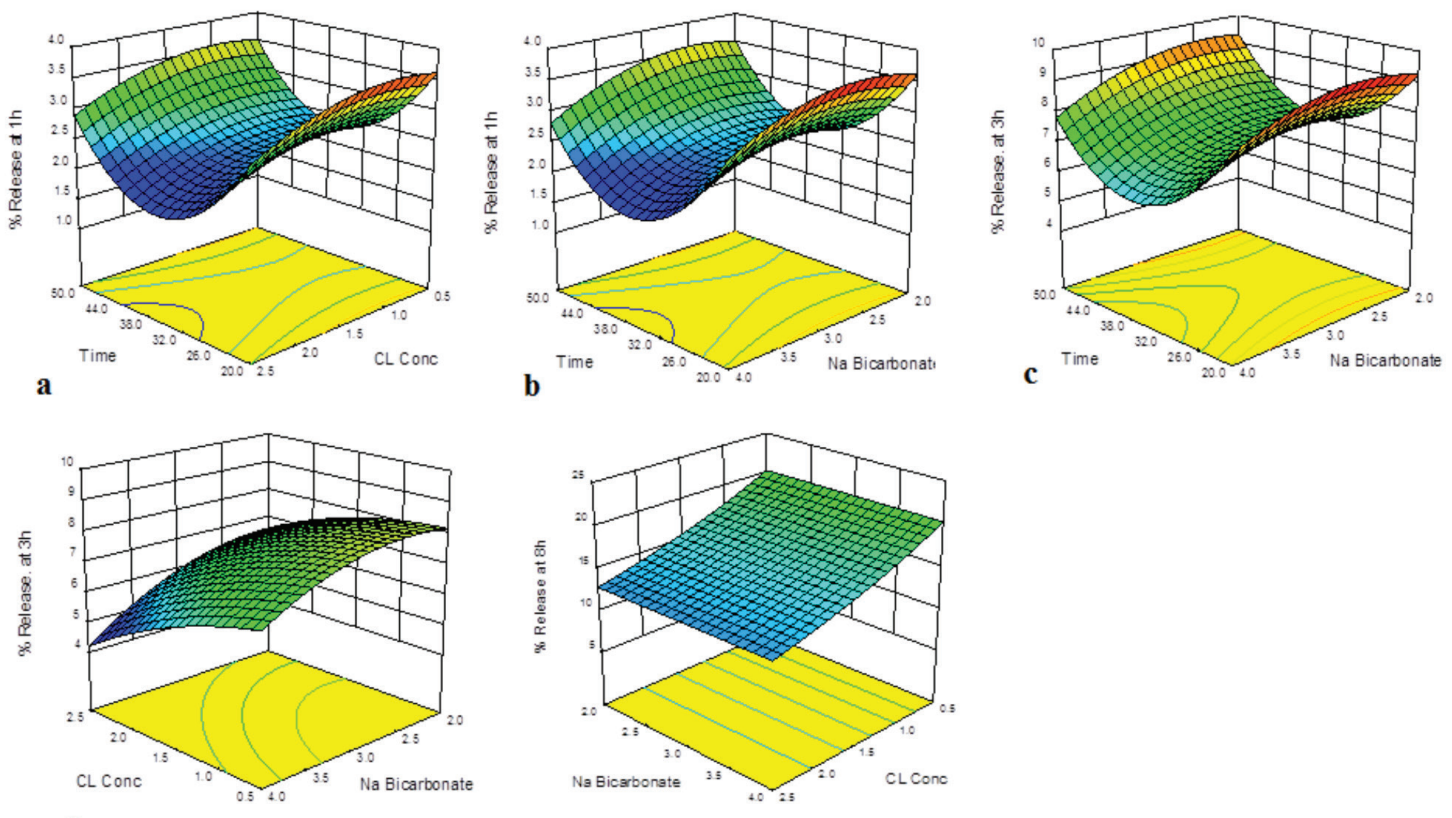

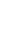

\section{d}

Figure 3. Combined effects of (a) irradiation time and cross-linker concentration, (b) irradiation time and sodium bicarbonate at $1 \mathrm{~h}$, (c) salt and irradiation time, (d) salt and cross-linker on drug release at $3 \mathrm{~h}$, and (e) cross-linker and salt at $8 \mathrm{~h}$ 
was higher than that of the microwave-treated matrices. Figure $6 \mathrm{~b}$ illustrates the interaction of the formulation ingredients and the drug in the optimized and control formulations. The peak temperature of paracetamol shifted from $169.79^{\circ} \mathrm{C}$ to $120^{\circ} \mathrm{C}-160^{\circ} \mathrm{C}$ as other components were added to the formulation. Generally, the optimized formulations had two major peaks at $69.65^{\circ} \mathrm{C}-91.89^{\circ} \mathrm{C}$ and $118.81^{\circ} \mathrm{C}-155.63^{\circ} \mathrm{C}$. The control formulation had one major peak $126.57^{\circ} \mathrm{C}-133.28^{\circ} \mathrm{C}$. The combined thermogram of all the optimized samples revealed some differences in peak temperature.

Table 2. Responses of the optimized and control formulations

\begin{tabular}{|c|c|c|c|c|c|c|}
\hline \multirow{3}{*}{ Time (h) } & \multicolumn{6}{|l|}{ Mean \pm SD } \\
\hline & \multicolumn{2}{|l|}{ Release (\%) } & \multicolumn{2}{|c|}{ Coefficient of variance } & \multicolumn{2}{|c|}{ Mean dissolution time } \\
\hline & $\begin{array}{l}\text { Validation } \\
\text { formulations }\end{array}$ & $\begin{array}{l}\text { Control } \\
\text { formulations }\end{array}$ & $\begin{array}{l}\text { Validation } \\
\text { formulations }\end{array}$ & $\begin{array}{l}\text { Control } \\
\text { formulations }\end{array}$ & $\begin{array}{l}\text { Validation } \\
\text { formulations }\end{array}$ & $\begin{array}{l}\text { Control } \\
\text { formulations }\end{array}$ \\
\hline 0.083 & $0.259 \pm 0.0566$ & $0.403 \pm 0.1159$ & $34.325 \pm 28.9560$ & $27.993 \pm 21.8610$ & $0.040 \pm 0.0000$ & $0.040 \pm 0.0000$ \\
\hline 0.25 & $0.597 \pm 0.0715$ & $0.780 \pm 0.1562$ & $22.813 \pm 15.9570$ & $17.630 \pm 16.9270$ & $0.113 \pm 0.0058$ & $0.103 \pm 0.0115$ \\
\hline 0.5 & $1.108 \pm 0.0953$ & $1.287 \pm 0.1888$ & $17.240 \pm 9.4518$ & $20.037 \pm 9.1173$ & $0.237 \pm 0.0115$ & $0.210 \pm 0.0200$ \\
\hline 0.75 & $1.577 \pm 0.0904$ & $1.770 \pm 0.2816$ & $13.897 \pm 6.3350$ & $17.317 \pm 9.5348$ & $0.350 \pm 0.0173$ & $0.323 \pm 0.0115$ \\
\hline 1 & $1.866 \pm 0.1543$ & $2.073 \pm 0.2272$ & $12.830 \pm 6.2367$ & $16.820 \pm 10.5052$ & $0.430 \pm 0.0100$ & $0.403 \pm 0.0321$ \\
\hline 2 & $3.639 \pm 0.2180$ & $3.923 \pm 0.5237$ & $8.360 \pm 2.6254$ & $17.857 \pm 11.9501$ & $0.953 \pm 0.0252$ & $0.923 \pm 0.0153$ \\
\hline 3 & $5.102 \pm 0.3239$ & $5.793 \pm 0.4143$ & $6.730 \pm 1.2869$ & $17.673 \pm 10.7575$ & $1.397 \pm 0.0115$ & $1.433 \pm 0.0666$ \\
\hline 5 & $7.658 \pm 0.6042$ & $8.513 \pm 0.4153$ & $7.865 \pm 2.6375$ & $18.960 \pm 7.9269$ & $2.267 \pm 0.0503$ & $2.257 \pm 0.1002$ \\
\hline 8 & $10.993 \pm 1.1533$ & $11.957 \pm 0.7836$ & $7.233 \pm 0.9347$ & $18.350 \pm 6.1724$ & $3.533 \pm 0.1350$ & $3.460 \pm 0.1493$ \\
\hline
\end{tabular}

SD: Standard deviation
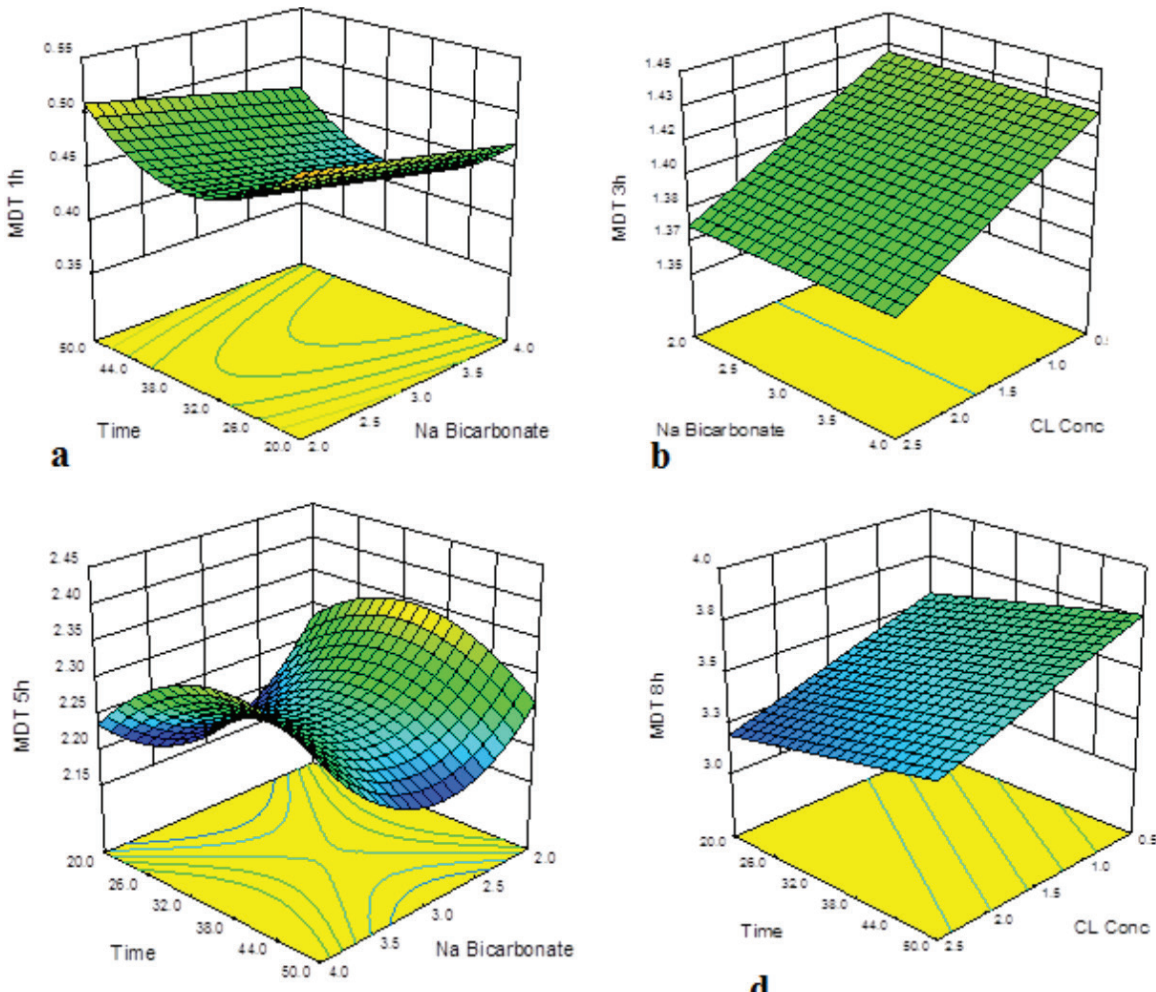

C

d

Figure 4. Combined effects of (a) irradiation time and cross-linker concentration on MDT at $1 \mathrm{~h}$, (b) irradiation time and sodium bicarbonate at $3 \mathrm{~h}$, (c) salt and irradiation time at $5 \mathrm{~h}$, and (d) irradiation time and cross-linker on MDT at $8 \mathrm{~h}$

MDT: Mean dissolution time 


\section{DISCUSSION}

The maximum effective temperature that could induce crosslinking was $60^{\circ} \mathrm{C}$, which was obtained at the minimum microwave energy of $30 \%$ in a short duration of $50 \mathrm{~s}$. The percentage of paracetamol released from matrices 8 and 9 was higher after 6 h. By comparison, $35.51 \%$ paracetamol release was observed in the other matrices at $8 \mathrm{~h}$. This difference might be ascribed to variations in drug diffusivity behavior and possible structural damage of gel matrices during dissolution. ${ }^{17}$ Using a cross-linker and microwave energy reduced the percentage of drug release, which seemed to be an optimal extended release pattern from the resulting cross-linked swellable gelatin matrices. The high $\mathrm{CV}$ in the drug release of the majority of matrices at the initial time interval was decreased at terminal time intervals possibly because of a decrease in porosity, leading to compact crosslinking in matrices. An increase in MDT after $8 \mathrm{~h}$ suggested that the dissolution of paracetamol from the gel matrices was considerably slower than that of paracetamol from the pure solution. The drug released from most of the microwave-treated cross-linked matrices was best described by the Peppas model. Conversely, the drug released from matrix 18 followed the first-
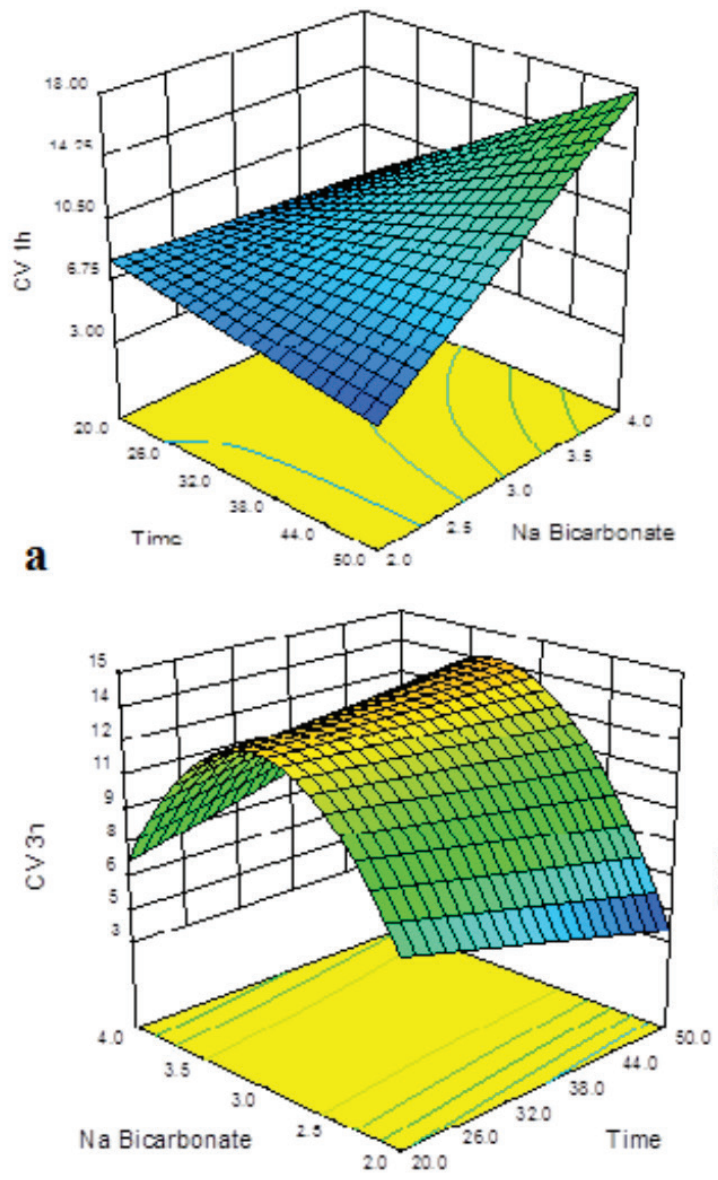

c order kinetics. The diffusional exponent, $\mathrm{n}$ between 0.5 and 1 supported the combined involvement of Fickian diffusion and macromolecule chain relaxation (anomalous or non-Fickian transport) during drug dissolution. ${ }^{18}$ However, only response surface plots exhibiting the prominent effects on drug release are shown here. Drug release was considerably controlled by the duration of microwave exposure and the concentrations of maize and sodium bicarbonate. This phenomenon was caused by the cross-linking of gelatin under a suitable combination of factors, as described in an earlier report, ${ }^{10}$ which demonstrated that a cross-linked gelatin product requires the presence of suitable combinations of all components (gelatin, sugar, and salt) to effectuate cross-linking. ${ }^{10}$ In the present study, a low percentage of paracetamol release, at $1 \mathrm{~h}$ was achieved at the middle levels of irradiation time, coupled with any amount of cross-linker or salt (Figure 3a, b, respectively). At 2 h, a low drug release was accomplished with the middle levels of exposure time, complemented with the higher amount of salt (Figure 3c) and higher concentrations, both of cross-linker and salt (Figure $3 \mathrm{~d}$ ). At $8 \mathrm{~h}$, the higher amount of cross-linker coupled with all the concentrations of salt resulted in a lower percent of paracetamol release (Figure 3e).
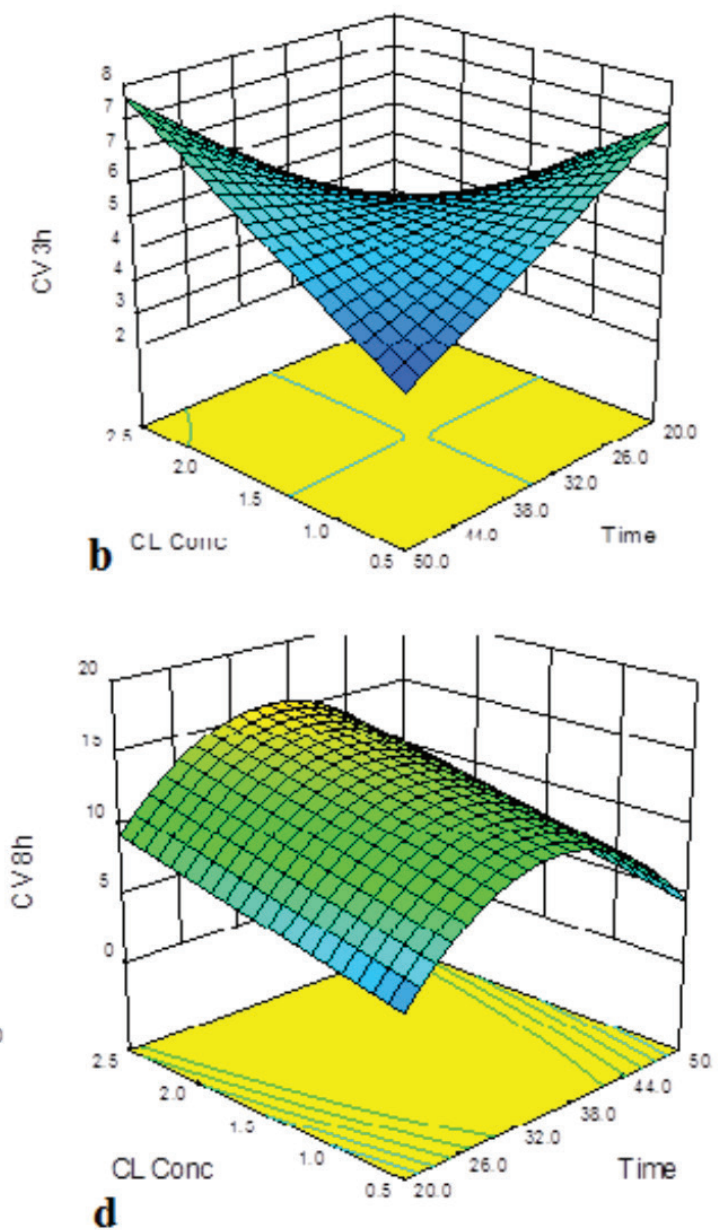

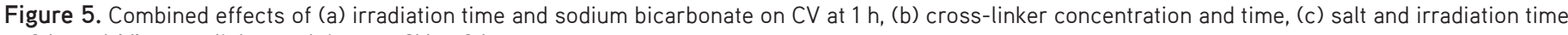
at $3 \mathrm{~h}$, and (d) cross-linker and time on CV at $8 \mathrm{~h}$

CV: Coefficient of variance 
The long irradiation time alone failed to reduce the percentage of drug release at $8 \mathrm{~h}$ when a lesser amount of the crosslinker and salt were present in the matrices. Our findings were consistent with previous report, ${ }^{6}$ which showed that the brief duration of microwave irradiation favored the sustained release characteristics of ketoprofen matrix beads. By contrast, long irradiation conferred the immediate release features possibly because of the effects of irradiation time on matrix porosity and the solid state of the drug in the gel matrix. MDTs at 1, 3, and $8 \mathrm{~h}$ were low at high salt and cross-linker concentrations and long microwave exposure. The saddle-shaped response plot of MDT at 1 and $5 \mathrm{~h}$ revealed the non-linear effect of the above factors on MDT. The duration of microwave exposure increased CV, whereas moderately high sodium bicarbonate concentrations could increase CV only at high microwave exposure. Thus, low CV was related to a comparatively shorter regime of microwave irradiations, suggesting high precision and reliability under microwave heating conditions. Controlling and limiting variations in outputs show the consistent quality of products and are critically required in research and industrial settings. ${ }^{19,20}$ A low percentage of drug release, a low CV, and a high MDT were the desired characteristics for the optimized matrices. A high MDT indicates a good releaseretarding ability of a cross-linked system. ${ }^{21}$ In our study, three control matrices were prepared by classical heating at $60^{\circ} \mathrm{C}$ The controlled and optimized formulations had almost similar percentage of drug release and followed the Peppas model. Heating by either classical or microwave facilitated the crosslinking of macromolecular (gelatin) chains in the presence of the cross-linker and salt. The decrease in the percentage of drug release from the gelatin matrices prepared via exposure to $330 \mathrm{~W}$ of microwave energy for $20-60 \mathrm{~s}$ was an indirect evidence of cross-linking. However, microwave exposure in this study was shorter than that in another study (10 $\mathrm{min}$ ) that generated a temperature range of $150^{\circ} \mathrm{C}-250^{\circ} \mathrm{C}$ in the preparation of gelatin microspheres. Gelatin is sensitive to and is modulated at low temperatures, ${ }^{4,22}$ particularly in the presence of cross-linker. The same finding was observed in

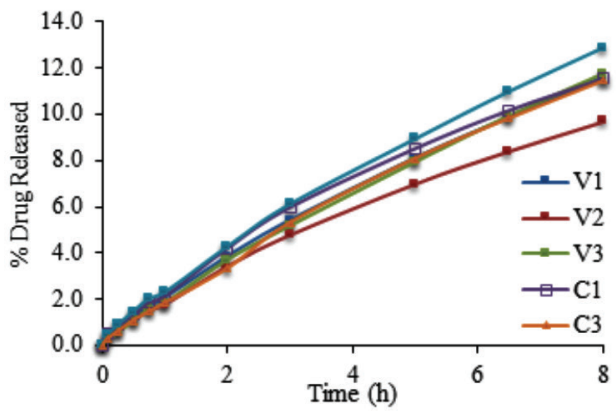

a the present study. An appropriate concentration of crosslinkers (genipin and glutaraldehyde) improves the mechanical strength and thermal stability of gelatin films. ${ }^{23}$ In the present study, cross-linking occurred via a chemical interaction between sugar (maize) and gelatin under controlled heating. Cortesi et al. ${ }^{24}$ demonstrated that sugars react with gelatin via two main reactions. One reaction is called Amadori rearrangement through which the gelatin amino group (lysyl $\varepsilon$-amino group) reacts with the aldehyde group of sugar to produce a cationic imine that rearranges to form a methylene link between $2 \varepsilon$-amino groups of lysine. As a result, a crosslinked structure is formed. In the other reaction, the carbonyl group of an open-chain sugar form reacts with free amino groups of gelatin. After a number of tautomerizations, a ketose sugar is produced. This carbonyl adduct can further associate with another amine group, thereby forming a cross-linked structure. $^{24}$ The DSC thermograms supported the crosslinking (Figure 6b). Consistent with previous findings, ${ }^{25}$ our results revealed that pure paracetamol showed a sharp melting endotherm at $169.79^{\circ} \mathrm{C}$ because of the crystalline nature of the drug. The DSC curves of maize and gelatin had shallow endotherms because of their poor thermal conductivity, ${ }^{26}$ illustrating a gradual structure loss over time. The DSC curves of the microwave heat-treated (V1, V2, and V3) formulations and the classical heat-treated formulations ( $1, C 2$, and $C 3$ ) exhibited a curve with variable endothermic peak positions. Overall, the peak broadened as the melting temperatures decreased from $126.57^{\circ} \mathrm{C}$ to $133.28^{\circ} \mathrm{C}$ probably because of a decreased drug crystallinity caused by drug-polymer crosslinking. The findings also demonstrated different levels of cross-linking with different types of heat treatments of the samples as depicted by varied peak positions. Controlling various parameters, such as heating rate, placement of sample, and amount of sample either in classical or microwave heating methods, probably influenced the thermal behavior of the matrices. As expected, relatively better standard deviation, i.e., lesser varied peak positions, were observed in microwave heating than in classical heating.

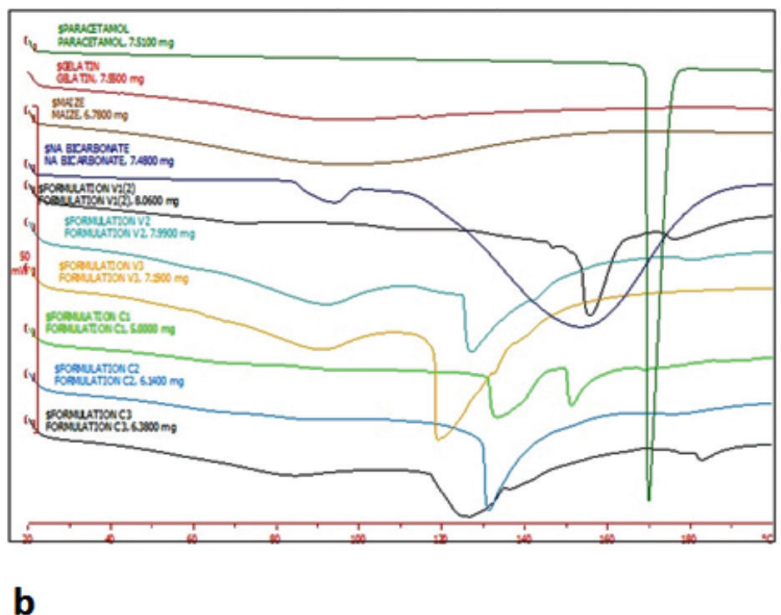

b

Figure 6. (a) Drug release (\%) of the validation and control formulations. (b) Combination of ingredients and optimized and control formulation thermograms 
The matrices prepared via classical heating (control) and microwave did not differ. However, the optimized and control matrices varied in the percentage of drug release at $5 \mathrm{~h}, \mathrm{CV}$ at $5 \mathrm{~h}, \mathrm{CV}$ at $8 \mathrm{~h}$, and MDT at $0.75 \mathrm{~h}$. Interestingly, the output of microwave exposure was having low variations (indicated by low standard deviation) and consistent quality obtained within a short period. The consistent quality of a sustained release carrier could ensure a consistent drug delivery in terms of correct timing and accurate dosage. This discriminative effect of microwave irradiation was probably attributed to its ability to penetrate a specimen with a uniform amount of heat, thereby facilitating an appropriate aldehyde cross-linking with an amino group of gelatin. ${ }^{4}$ Thermal analysis via DSC indicated the interaction between paracetamol and other ingredients, as shown by the left peak shift. A previous study reported the chemical stability of a drug embedded in a matrix generated via microwave irradiation. Hence, paracetamol in this study was expected to sustain its stability. ${ }^{27,28}$ Although the combined thermograms of all the optimized samples showed some differences in peak temperature, endothermic enthalpy may be caused by the storage duration of samples. ${ }^{29}$ Nevertheless, the microwave may be an effective approach for the preparation of sustained release matrices with better reproducibility (outputs lower variation) as compared to the conventional heating approach.

\section{Study limitations}

The time for the complete release of paracetamol was not determined. The non-thermal effects of microwave irradiation were also not assessed. These parameters should be explored in future studies.

\section{CONCLUSION}

Cross-linked gelatin treated with microwave could sustain the release of paracetamol compared to that of the paracetamol solution alone. As indicated by the relative standard deviation in the formulations, the microwave-treated cross-linked gelatin formulations yielded consistent release and lower variations in the release data compared with those prepared via classical heating. DoE could be used as a tool to optimize these conditions. Therefore, microwave heating could be applied to produce a consistent quality of pharmaceutical products.

\section{ACKNOWLEDGMENTS}

The corresponding author acknowledges the research grant [B01/05-Res(03)08] from International Medical University, Kuala Lumpur, Malaysia.

Conflicts of interest: No conflict of interest was declared by the authors. The authors alone are responsible for the content and writing of the paper.

\section{REFERENCES}

1. Ching A, Liew C, Heng P, Chan L. Impact of cross-linker on alginate matrix integrity and drug release. Int J Pharm. 2008;355:259-268.
2. Bhavsar MD, Tiwari SB, Amiji MM. Formulation optimization for the nanoparticles-in-microsphere hybrid oral delivery system using factorial design. J Control Release. 2006;110:422-430.

3. Dong Z, Wang Q, Du Y. Alginate/gelatin blend films and their properties for drug controlled release. J Membr Sci. 2006;280:37-44.

4. Vandelli MA, Romagnoli M, Monti A, Gozzi M, Guerra P, Rivasi F, Forni F. Microwave-treated gelatin microspheres as drug delivery system. J Control Release. 2004;96:67-84.

5. Larraneta E, Lutton RE, Brady AJ, Vicente-Pérez EM, Woolfson AD, Thakur RRS, Donnelly RF. Microwave-assisted preparation of hydrogelforming microneedle arrays for transdermal drug delivery applications. Macromol Mater Eng. 2015;300:586-595.

6. Auriemma G, Del Gaudio P, Barba AA, d'Amore M, Aquino RP. A combined technique based on prilling and microwave assisted treatments for the production of ketoprofen controlled release dosage forms. Int J Pharm. 2011; 415:196-205.

7. Fini A, Breccia A. Chemistry by microwaves. Pure Appl Chem. 1999; 71:573-579.

8. Qasem RJ. The effect of microwave thermal denaturation on release properties of bovine serum albumin and gluten matrices. AAPS PharmSciTech. 2006;7:E104-E110.

9. Yang $X$, Patel S, Sheng $Y$, Pal D, Mitra AK. Statistical design for formulation optimization of hydrocortisone butyrate-loaded PLGA nanoparticles. AAPS PharmSciTech. 2014;15:569-587.

10. Hussain T, Hussain A, Shamim R, Shehzad MK, Danish Z, Hussain K, Bukhari NI. Development and in-vitro evaluation of floating gastroretentive matrix tablet for a model water soluble drug prepared with the novel blends of chitosan and polycaprolactone. Lat Am J Pharm. 2015;34:1849-1857.

11. Corti G, Maestrelli F, Cirri M, Zerrouk N, Mura P. Development and evaluation of an in vitro method for prediction of human drug absorption: II. demonstration of the method suitability. Eur J Pharm Sci. 2006;27:354362.

12. Giannakou S, Dallas P, Rekkas D, Choulis N. In vitro evaluation of nimodipine permeation through human epidermis using response surface methodology. Int J Pharm. 2002;241:27-34.

13. Lucero MJ, Claro C, Casas M, Jiménez-Castellanos MR. Drug diffusion from disperse systems with a hydrophobically modified polysaccharide: Enhancer ${ }^{\circledR}$ vs Franz cells. Carbohydr Polym. 2013;92:149-156.

14. Jana S, Manna S, Nayak AK, Sen KK, Basu SK. Carbopol gel containing chitosan-egg albumin nanoparticles for transdermal aceclofenac delivery. Colloids Surf B Biointerfaces. 2014;114:36-44.

15. Dragicevic-Curic N, Scheglmann D, Albrecht V, Fahr A. Development of different temoporfin-loaded invasomes-novel nanocarriers of temoporfin: Characterization, stability and in vitro skin penetration studies. Colloids Surf B Biointerfaces. 2009;70:198-206.

16. Huang YB, Tsai YH, Lee SH, Chang JS, Wu PC. Optimization of pHindependent release of nicardipine hydrochloride extended-release matrix tablets using response surface methodology. Int J Pharm. 2005;289:87-95.

17. Kantaria S, Rees GD, Lawrence MJ. Gelatin-stabilised microemulsionbased organogels: rheology and application in iontophoretic transdermal drug delivery. J Control Release. 1999;60:355-365.

18. Serra L, Doménech J, Peppas NA. Drug transport mechanisms and release kinetics from molecularly designed poly (acrylic acid-g-ethylene glycol) hydrogels. Biomaterials. 2006;27:5440-5451. 
19. Lourenço V, Lochmann D, Reich G, Menezes JC, Herdling T, Schewitz J. A quality by design study applied to an industrial pharmaceutical fluid bed granulation. Eur J Pharm Biopharm. 2012;81:438-447.

20. Siepmann J, Peppas N. Modeling of drug release from delivery systems based on hydroxypropyl methylcellulose (HPMC). Adv Drug Deliv Rev. 2012;64:163-174.

21. Li-Fang F, Wei H, Yong-Zhen C, Bai X, Qing D, Feng W, Min Q, De-Ying C. Studies of chitosan/Kollicoat SR 30D film-coated tablets for colonic drug delivery. Int J Pharm. 2009;375:8-15.

22. Santoro M, Tatara AM, Mikos AG. Gelatin carriers for drug and cell delivery in tissue engineering. J Control Release. 2014;190:210-218.

23. Amadori S, Torricelli P, Rubini K, Fini M, Panzavolta S, Bigi A. Effect of sterilization and crosslinking on gelatin films. J Mater Sci Mater Med. 2015;26:69.

24. Cortesi R, Esposito E, Osti M, Menegatti E, Squarzoni G, Davis SS, Nastruzzi C. Dextran cross-linked gelatin microspheres as a drug delivery system. Eur J Pharm Biopharm. 1999;47:153-160.
25. Sibik J, Sargent MJ, Franklin M, Zeitler JA. Crystallization and phase changes in paracetamol from the amorphous solid to the liquid phase. Mol Pharm. 2014;11:1326-1334.

26. Sandhu KS, Singh N, Kaur MJ. Characteristics of the different corn types and their grain fractions: physicochemical, thermal, morphological, and rheological properties of starches. J Food Eng. 2004;64:119-127.

27. Nurjaya S, Wong T. Effects of microwave on drug release properties of matrices of pectin. Carbohydr Polym. 2005;62:245-257.

28. Loh Z, Liew C, Lee C, Heng P. Microwave-assisted drying of pharmaceutical granules and its impact on drug stability. Int J Pharm. 2008;359:53-62.

29. Fan $H$, Dash, AK. Effect of cross-linking on the in vitro release kinetics of doxorubicin from gelatin implants. Int J Pharm. 2001;213:103-116. 